\title{
KALENDER PETANI DAN SUMBER PENGETAHUAN TENTANG MUSIM TANAM
}

\author{
Budi Gustaman \\ Departemen Sejarah \& Filologi \\ Fakultas Ilmu Budaya, Universitas Padjadjaran \\ budi.gustaman@unpad.ac.id
}

\begin{abstract}
Abstrak
Di wilayah tropis seperti Jawa, pergantian musim menjadi sumber pengetahuan penting bagi kehidupan agraris. Siklus pergantian musim, dengan berbagai tanda dan gejala alam pada setiap musimnya, adalah kalender bagi para petani. Kalender tersebut menjadi panduan dalam menentukan pekerjaan agraris, seperti menanam, memanen, dan sebagainya. Penelitian ini berusaha untuk mendeskripsikan sumber pengetahuan tentang musim tanam yang disebut Pranatamangsa. Sumber pengetahuan ini ditulis dalam beberapa naskah, serta dideskripsikan ulang dalam tulisan-tulisan orang Eropa. Metode yang digunakan dalam penelitian ini adalah metode sejarah, yang terdiri dari tahap heuristik, kritik, interpretasi, dan historiografi. Penelitian ini menunjukkan bahwa sistem pengetahuan pranatamangsa muncul dari pemaknaan terhadap kondisi geografis dan ekologis Jawa yang bercorak agraris. Sistem pengetahuan ini mengalami pembakuan oleh Sunan Pakubuwono VII pada 1855, dengan sistem perhitungan dan penanggalan yang seragam untuk mengatahui setiap pergantian musimnya. Secara praktis, pengetahuan ini mulai memudar di masa kini seiring dengan berkembangnya ilmu pengetahuan modern. Selain itu, terjadinya ketidakpastian iklim juga menjadi faktor penting bagi lunturnya pranatamangsa.
\end{abstract}

Kata Kunci: Iklim, Musim, Pranatamangsa, Pertanian, Jawa

\begin{abstract}
In a tropical island like Java, Indonesia, seasons' changing is an important source of knowledge, especially for its agraricultural society. The cycle of seasons shows signs and symptoms in every season. This traditional system of organizing time has long served as a calendar and a guide in their work. This research seeks to describe the origin of such knowledge known as Pranatamangsa manuscript. The source of the knowledge is written in the manuscripts and then redescribed in writings by Europeans. The method used in this research is the historical method, which consists of heuristic, criticism, interpretation, and historiography. This research shows that pranatamangsa knowledge system arises from understanding the geographical and ecological conditions of agrarian Java. This knowledge system improved the standardization by Sunan Pakubuwono VII in 1855, with a uniformed calculation and calendar system to know each change of season. In the present time, this knowledge gradually ceases to exist in the face of modern science and climate uncertainty, which is also another contributing factor.
\end{abstract}

Keywords: Climate, Seasons, Pranatamangsa, Agrarian, Java

\section{PENDAHULUAN}

Perubahan iklim merupakan salah satu persoalan dunia. Meningkatnya temperatur udara dan tidak menentunya pola curah hujan, menimbulkan berbagai bencana alam, memburuknya kualitas kesehatan, serta terancamnya ketersediaan pangan. Terkait persoalan terakhir, ketidakpastian cuaca seringkali menimbulkan bencana kekeringan serta bencana banjir. Lahan pertanian terkena imbasnya sehingga kerap 
terjadi gagal panen. Kondisi ini tentu sangat merugikan, terlebih masyarakat Indonesia sangat bertumpu pada sektor agraris.

Pengetahuan tentang iklim memang sangat berguna bagi pertanian. Datang dan berakhirnya musim hujan dan kemarau sangat menentukan bagi waktu bercocok tanam, hingga saat menuai panen. Pada zaman sekarang, sumber pengetahuan tentang iklim dan cuaca (untuk pertanian) bertumpu pada ilmu pengetahuan modern, yang memadukan berbagai disiplin ilmu, seperti meteorologi, ilmu tanah, hidrologi, agronomi, dan sebagainya. Lalu, bagaimana cara para petani menentukan waktu bertanam sebelum berkembangnya bidang-bidang keilmuan tersebut? Salah satu sumber pengetahuan tersebut ialah Pranatamangsa.

Pranatamangsa atau Pranotomongso adalah sistem penanggalan musim petani Jawa, berdasarkan pembacaan terhadap berbagai tanda-tanda alam, seperti kemunculan bintang, gerak angin, serta penampakkan fisik flora dan gerak-gerik fauna. Sindhunata (2011: 2) menyebutkan bahwa sistem ini adalah budaya petani yang telah mendarah-daging dalam kehidupan petani Jaw dan Sunda. Pranatamangsa telah digunakan sebelum datangnya pengaruh Hindu. Pranatamangsa (diduga) menyumbang bagi kebesaran negara-negara agraris, seperti Mataram Kuno, Pajang, dan Mataram Islam.

Sistem pengetahuan tersebut memang bersandar pada kondisi geografis Nusantara. Penciptaan pranatamangsa adalah pengetahuan terhadap siklus iklim tropis. Musim hujan dan kemarau sebagai siklus tahunan dengan berbagai tandatanda alam yang mengiringinya. Bagi masyarakat agraris, tanda-tanda alam adalah kalender, yang pada setiap pembagian waktunya memiliki ciri, watak dan makna tertentu, baik secara denotatif ataupun konotatif. Pada akhirnya, pranatamangsa terus mengalami penyempurnaan secara praktik, dan terus mengalami pelbagai pemaknaan secara teoritis. Untuk hal yang terakhir, pranatamangsa tidak lepas dari perhatian orang-orang Eropa. Dalam berbagai catatan atau tulisan orang-orang Eropa, pranatamangsa adalah salah satu aspek penting tentang Jawa dan Hindia. Terlepas dari ada atau tidaknya tendensi politis terkait pemaknaannya, pranatamangsa tetap menjadi sumber pengetahuan bagi orang-orang Eropa dalam memahami karakteristik ekologi dan kultur masyarakatnya. J.J.B. Ostmeier dalam buku Punten en Problem; Een en Ander Over Het Javaansche Volk bahkan memperlihatkan kekagumannya perihal pengadopsian orang Jawa pada kalender petani. Ia menyebutkan: "Mungkin tidak diketahui secara umum bahwa orang Jawa lebih baik daripada kita pada masanya. Kita hanya dapat menggunakan penanggalan Romawi, terkecuali hal itu, orang Jawa memiliki akses pada penanggalan Jawa dan Arab, pranotomongso-nya, selain juga mengikuti perhitungan Hindu kuno ke dalam windu dan wuku." (Ostmeier, 1914: 142).

Tulisan ini hendak memaparkan tinjauan umum terkait pranatamangsa sebagai sistem penanggalan para petani di masa lalu. Masalah utama yang dipertanyakan dalam tulisan ini adalah 'bagaimana' perkembangan subtansi pranatamangsa sebelum dan sesudah pembakuan. Selain itu, dipertanyakan pula perihal 'bagaimana' orang-orang Eropa menilai dan memmbahas perihal pranatamangsa. Sumber-sumber yang digunakan ialah Serat Centhini dan Kitab Paririmbon. Selain itu, digunakan pula studi-studi kolonial yang membahas soal pranatamangsa. Dalam hal ini, pranatamangsa ternyata telah diulas dalam beberapa 
tulisan orang-orang Eropa, hingga penerjemahan lebih lanjut secara praktik dan teoritis pada masa kini.

\section{METODE PENELITIAN}

Metode yang digunakan dalam penelitian ini ialah metode sejarah, yang terdiri atas empat tahap, yakni heuristik, kritik, interpretasi, dan historiografi. Dalam proses penelitian, kajian ini berusaha untuk meninjau sumber-sumber yang ditulis orang Eropa, sekaligus melihat perkembangan substansi sistem pranatamangsa sejak masa lalu hingga masa kini. Ada tiga sumber yang dikaji dalam penelitian ini. Pertama, buku The Malay Archipelago (1820) karya John Crawfurd, sebagai karya orang Eropa yang (mungkin) tertua yang mengulas pranatamangsa. Selanjutnya, karya-karya orang Belanda seperti H.A. van Hien berjudul De Petangan's of Telingen der Javanen (terbit pada 1897) diulas dalam tulisan ini. Selain itu, ada pula tulisan J.J.B. Ostmeier, dalam buku Punten en Problemen Javaansche Volk. Ulasan-ulasan terkait Serat Centhini dan Kitab Paririmbon juga digunakan untuk mengelaborasi substansi terkait sistem pranatamangsa.

\section{HASIL DAN BAHASAN}

\section{Catatan Crawfurd tentang Kalender Petani}

John Crawfurd dalam buku The Malay Archipelago jilid I, secara khusus menjelaskan perihal sistem kalender yang digunakan masyarakat di Nusantara, khususnya Jawa. Ia mengawali penjelasannya dari adanya pengadopsian 4 sistem waktu oleh masyarakat Jawa, yakni perhitungan pribumi Jawa, perhitungan Hindu, perhitungan Arab, serta ditambah dengan perhitungan tanggal menurut orang Eropa (barat). Setiap penanggalan memiliki aturan dan kerumitan tersendiri. Crawfurd menyoroti sistem penanggalan petani Jawa, yang ia sebut rural calender. Penanggalan ini didasarkan pada ketetapan astrologi atau ilmu perbintangan. Penanggalan ini membagi hari menjadi 30 bagian, yang disebut Wuku.

Wuku sejatinya merupakan rasi bintang atau konstelasi bintang. Pengertiannya merujuk pada sekelompok bintang di langit yang tampak berhubungan dan membentuk suatu konfigurasi tertentu. Suatu konfigurasi bintang tertentu memiliki arti sebagai sumber pengetahuan untuk menentukan awal musim kemarau, dan musim hujan, sehingga bisa menjadi pertanda untuk memulai musim tanam ataupun waktu berlayar (Chodjim, 2019: 351-352).

Dalam hal ini, pengaturan musim memiliki perhitungan khusus, yang disebut Pranata Mangsa. Crawfurd pun sampai pada pembahasan ini. Ia menjelaskan bahwa masyarakat petani Jawa membagi tahun menjadi dua belas musim dalam masingmasing panjang hari yang tidak sama. Jumlah seluruh hari dalam satu tahun ialah 360 hari. Pembagian tersebut (secara berturut-turut) adalah sebagai berikut: Kaso 41 hari; Karo 23 hari; Katigo 24 hari; Kapat 24 hari; Kalimo 26 hari; Kanam 41 hari; Kapitu 41 hari; Kawolu 26 hari; Kasongo 25 hari; Kasapuluh 25 hari; Dasto 23 hari; dan Sodo 41 hari (Crawfurd, 1820: 293-294).

Setiap musim memiliki karakteristik tersendiri disertai pekerjaan yang harus dilakukan oleh petani pada setiap musimnya. Pada musim pertama, ditandai dengan bergururannya daun-daun. Para petani diharuskan untuk membakar rumput kering dan menebang pohon untuk budidaya padi gunung (Humah). Selanjutnya, pada 
musim ke-2, musim ditandai dengan dimulainya penanaman vegetasi. Musim ke-3 ditandai dengan tumbuhnya tanaman-tanaman liar dan para petani diharuskan menyibukkan diri dengan menanam ubi, kacang-kacangan, dan tanaman sekunder lainnya. Musim ke-4 merupakan musim cinta atau musim berkembangbiaknya binatang liar. Angin sangat kencang pada musim ini serta sungai-sungai mulai penuh. Pada musim ke-5, para petani diharuskan untuk mempersiapkan penanaman atau budidaya padi sawah, dengan memeriksa saluran air dan memperbaiki bendungan. Pada musim ke-6, para petani diharuskan untuk membajak tanah dan mulai menabur benih padi. Pada musim ke-7, petani mulai memindahkan tanaman padi dan memeriksa saluran air. Musim ke-8 ditandai dengan mulai tumbuhnya tanaman padi dan para petani harus meningkatkan kapasitas air pada bendungan atau saluran irigasi. Pada musim ke-9, biji padi telah terlihat. Musim ke-10 ditandai dengan mulai menguningnya dan matangnya biji padi. Pada musim ke-11, tanaman padi telah matang dan panen dimulai. Pada musim terakhir, musim hujan dimulai. Waktu panen selesai dan padi disimpan (Crawfurd, 1820: 299).

Pembagian musim di atas memperlihatkan pentingnya pengetahunan akan datangnya musim hujan, karena pada dasarnya penanaman padi membutuhkan pasokan air berlimpah. Dalam The History of Java, Raffles menilai bahwa air mengalir dalam jumlah besar di Jawa. Pembudidaya padi sawah mengalirkan air dari saluran utama menuju banyak kanal atau irigasi. Air diperoleh bukan hanya pada musim hujan, tetapi juga pada musim kemarau yang terik. Hal tersebut sangat menentukan melimpahnya hasil panen (Raffles, 1830: 119). Tidak seperti koleganya (Crawfurd), Raffles sendiri tidak menguraikan lebih jauh perihal rural calender. Namun demikian, kedua orang Inggris tersebut sama-sama mengagumi sistem pertanian masyarakat Jawa.

"Penemu kalender pedesaan ini ditentukan oleh penerapannya pada iklim mereka, dan terhadap modifikasi musim yang khas, yang tidak berlaku untuk wilayah kepulauan lainnya ... Dari deskripsi tentang ekonomi pedesaan mereka, kami menyimpulkan bahwa pada periode penciptaan kalender tersebut, orang Jawa sudah sangat memiliki keahlian dalam pertanian. Musim-musim secara prinsip ditentukan berdasarkan budaya peningkatan cabang pertanian mereka, besarnya hasil panen yang dibudidayakan..." (Crawfurd, 1820: 297-298).

Meski demikian, Crawfurd menilai bahwa mekipun pembagian rural calender terlihat baik dalam karakter setiap musimnya, susunan (jumlah hari) dalam beberapa tingkat berubah-ubah. Hal ini terlihat pada musim pertama dan terakhir. Musim lainnya terlihat sama persis, kecuali pada musim ketiga, keempat serta kesembilan dan kesepuluh, dimana terdapat perbedaan satu hari (dengan jumlah perhitungan yang ditetapkan) (Crawfurd, 1820: 299). Tidak berhenti sampai di sini, sistem rural calender terus "diterjemahkan" oleh orang-orang Eropa sebagai sebuah sumber pengetahuan penting.

\section{Pembakuan Sistem Mangsa dan "Penyempurnaan" Deskripsi}

Narasi terkait sistem kalender petani Jawa terus diulas dalam beberapa tulisan yang umumnya mengulas tema-tema seputar kebudayaan Jawa. Menjelang 
pertengahan abad ke-19, ulasan terkait Pranotomongso mengalami beberapa penambahan seiring adanya upaya pembakuan sistem oleh Susuhunan Pakubuwono VII dari Surakarta pada 1852. Upaya tersebut dimaksudkan untuk menghindari perbedaan dalam perhitungan awal mongso serta perbedaan jumlah hari dalam satu mongso, yang berpengaruh pada kurang tepatnya pekerjaan sawah yang akan dilakukan dalam setiap mongso tertentu (Ostmeier, 1914: 143-144). Salah seorang peminat kebudayaan Jawa, H.A. van Hien, membahas terkait pranotomongso dalam buku berjudul De Petangan's of Telingen der Javanen (terbit pada 1897).

Dalam satu sub bab khusus, van Hien membahas perihal sistem pranatamangsa. Ia menuturkan bahwa penetapan ini telah disesuaikan dengan tahun matahari dan juga telah menyesuaikan perhitungannya menjadi 365 1/4 hari. Awal penetapan suatu mangsa baru ditentukan oleh pengamatan panjang bayangan seorang laki-laki yang berdiri, dan diukur dengan menggunakan kakinya sendiri. Misalnya, pada mangsa kasa akan terbentuk panjang 4 kaki pada sore hari, dan pada mangsa karo terbentuk panjang bayangan 3 kaki pada waktu yang sama. Prosedur lainnya ialah menggunakan tongkat tegak lurus pada bidang horizontal, dimana suatu mangsa ditentukan oleh jatuhnya garis bayangan sore pada arah tertentu. Contohnya, mangsa kasa dimulai ketika bayangan memanjang ke selatan, sedangkan sebaliknya arah utara menunjukkan awal mangsa kapitoe. Melalui prosedur ini, durasi setiap mangsa dapat dengan mudah ditentukan, baik dengan pengamatan maupun perhitungan (van Hien, 1897: 54 - 55).

Pembakuan sistem yang dilakukan oleh Sunan Pakubuwono VII mulai diikuti sejak 22 Juni 1855. Sebelum adanya pembakuan dan penyeragaman, kerapkali terjadi perbedaan durasi setiap mangsa. Para petani pun sangat bergantung pada hadir dan lenyapnya suatu rasi bintang tertentu. Berikut perhitungan pranatamangsa dikaitkan dengan penampakan rasi bintang.

\begin{tabular}{|c|c|c|c|c|c|}
\hline \multirow[b]{2}{*}{ Musim } & \multirow[b]{2}{*}{ Bintang } & \multirow[b]{2}{*}{ Mangsa } & \multicolumn{3}{|c|}{ Lamanya Mangsa } \\
\hline & & & $\begin{array}{l}\text { Jawa } \\
\text { Barat } \\
\end{array}$ & $\begin{array}{c}\text { Jawa } \\
\text { Tengah }\end{array}$ & $\begin{array}{l}\text { Jawa } \\
\text { Timur }\end{array}$ \\
\hline 1 & $\begin{array}{l}\text { Sapi } \\
\text { goemarang }\end{array}$ & Kasa (kartika) & 41 hari & 41 hari & 30 hari \\
\hline 2 & Tagih & Karo/Kalih (Poespa) & 23 hari & 25 hari & 30 hari \\
\hline 3 & Loemboeng & $\begin{array}{l}\text { Kateloe/Katiga } \\
\text { (Mangasri) }\end{array}$ & 24 hari & 24 hari & 30 hari \\
\hline 4 & $\begin{array}{l}\text { Djaran- } \\
\text { dhawoek }\end{array}$ & Kapat/Kasakawan (Setra) & 24 hari & 24 hari & 30 hari \\
\hline 5 & Banjak-angrem & $\begin{array}{l}\text { Kalima/Gangsal } \\
\text { (Manggakala) }\end{array}$ & 26 hari & 26 hari & 30 hari \\
\hline 6 & Gotong-majit & Kanem (Naja) & 41 hari & 41 hari & 30 hari \\
\hline 7 & Bisma-Sekti & Kapitoe (Palgoena) & 41 hari & 41 hari & 30 hari \\
\hline 8 & $\begin{array}{l}\text { Woelandjar- } \\
\text { ngirim }\end{array}$ & Kawoloe (Wisaka) & 26 hari & 26 hari & 30 hari \\
\hline 9 & Woeloeh & Kasanga (Djita) & 25 hari & 25 hari & 30 hari \\
\hline 10 & Waloekoe & $\begin{array}{l}\text { Kasadasa/Kasepoeloeh } \\
\text { (Srawana) }\end{array}$ & 25 hari & 25 hari & 30 hari \\
\hline 11 & Loemboeng & Desta (Ijoedrawana) & 23 hari & 26 hari & 30 hari \\
\hline 12 & Tagih & Sada (Asoedji) & $\begin{array}{l}41 \text { hari } \\
360 \text { hari }\end{array}$ & $\begin{array}{l}41 \text { hari } \\
365 \text { hari }\end{array}$ & $\begin{array}{l}30 \text { hari } \\
360 \text { hari }\end{array}$ \\
\hline
\end{tabular}


Sumber: Diolah dari Van Hien, H.A. 1897. De Petangan's of Tellingen der Javanen. Batavia: Albrecht \& Co. hlm., 55 - 56

Penampakkan rasi-rasi bintang tersebut merupakan pertanda bagi suatu gejala alam tertentu. Berikut ini merupakan gejala alam yang diterjemahkan dari rasi bintang yang muncul pada setiap mangsa-nya.

1. Bintang sapi-goemarang pada mangsa pertama (kasa). Tanda-tanda alam pada musim ini disebut Tata. Musim ini ditandai dengan bertiupnya angin dari sebelah timur laut yang arahnya kekiri dan kekanan (tidak searah), hujan yang bisa menjadi obat dan anginnya bisa membuang keringat jahat, hujan bisa menunmbuhkan segala macam biji-bijian, langit terlihat terang, serta bintang-bintang terlihat diam tidak bergerak.

2. Bintang tagih pada mangsa kedua (karo). Tanda-tanda alam pada musim ini disebut Gati. Musim ini ditandai dengan berhembusnya angin dari sebelah timur laut, angin terasa dingin di luar dan panas di dalam, bumi atau tanah retak, serta munculnya segala macam biji.

3. Bintang loemboeng pada mangsa ketiga (katiga). Tanda-tanda alam pada musim ini disebut Wisaja. Musim ini ditandai dengan hembusan angin dari sebelah utara yang bergerak sedang (terasa enak pada badan), pepohonan mulai tumbuh, bumi atau tanah berbau wangi dan asin, cahaya matahari terlihat kuning, langit nampak berwarna biru, terkadang angin bertiup keras, air terasa busuk, serta tanah merekah lebih lebar.

4. Bintang Djaran-dwawoek pada mangsa keempat (kapat). Tanda-tanda alam pada musim ini disebut Pantjawara. Musim ini ditandai dengan berhembusnya angin dari sebelah barat laut yang berjalan ke selatan membawa hujan, angin berjalan ke arah utara juga, angin sering berputar disertai hujan dan guntur, binatang berkaki empat kawin, daun-daun ribut, bumi terlihat hijau, langit terlihat kuning, ikan di air terlihat keluar, serta orang-orang terkena penyakit tumpah dan diare.

5. Bintang Banjak-angrem pada mangsa kelima (kalima). Tanda-tanda alam pada musim ini disebut Bajoe. Musim ini ditandai dengan angin berhembus dari barat laut yang berhembus dengan kencang. Hujan sering terjadi pada pagi dan sore, serta hujan yang turun tidak disertai angin. Bumi terlihat renges (subur), baunya wangi, serta semua tanaman hidup.

6. Bintang Gotong-majit pada mangsa keenam (kanem). Tanda-tanda alam pada musim ini disebut Oetara. Musim ini ditandai dengan berhembusnya angin dari sebelah barat dengan besar dan keras (kencang). Pada musim ini bumi dan langit sama rupanya, serta daun hijau mulai berwarna kuning. Selain itu, buah-buahan enak dimakan.

7. Bintang Bisma-sekti pada mangsa ketujuh (kapitoe). Tanda-tanda alam pada musim ini disebut Boewana. Musim ini ditandai dengan berhembusnya angin dari barat dengan besar, keras, dan berulang-ulang. Pada musim ini hujan sering turun siang dan malam. Banjir besar pun sering terjadi. Bumi atau tanah merembes, pohon kayu dan rumput terlihat diam, dan langit tidak terang. Manusia, burung, dan binatang terlihat kecil hati (sedih).

8. Bintang Woelandjar-ngirim pada mangsa kedelapan (kawoloe). Tanda-tanda alam pada musim ini disebut pawana. Pada musim ini angin datang dari 
sebelah timur-barat dengan berputar putar. Hujan jarang terjadi tetapi guntur kerap berbunyi. Bumi (tanah) terlihat putih dan langit terlihat hitam. Daun-daun terasa kasar dan manusia biasanya diam di rumah.

9. Bintang Woeloeh pada mangsa kesembilan (kasanga). Tanda-tanda alam pada musim ini disebut samirana. Pada musim ini angin datang dari sebelah timur dari arah sebelah bawah. Hujan nampak kencang, sangat dingin, tanaman dan pohon kayu mulai tumbuh. Bumi dan langit terlihat berwarna seperti tembaga dan hawanya terasa panas. Bumi dianggap sedang sakit.

10. Woeloekoe pada mangsa kesepuluh (kasadasa). Tanda-tanda alam pada musim ini disebut wisikan. Pada musim ini angin berhembus dari sebelah tenggara dengan keras dan panas. Bumi terlihat putih dan langit terlihat hitam. Manusia umumnya sakit.

11. Loemboeng pada mangsa kesebelas (desta). Tanda-tanda alam pada musim ini disebut tata. Pada musim ini angin berhembus dari sebelah tenggara dengan keras dan panas terutama pada malam hari. Buah-buahan mulai muncul serta semua tumbuhan setengah mati. Bumi bersuara keras. Orangorang terlihat capek dan sakit

12. Tagih pada mangsa keduabelas (sada). Tanda-tanda alam pada musim ini disebut pandhawa. Pada musim ini angin berhembus dari sebelah timur dengan keras dan tidak terputus-putus. Hawa sebentar-sebentar terasa dingin dan panas. Tanah terpecah-pecah dan pohon kayu menjadi layu. Orang-orang sakit demam (van Hien, 1987: 60-62).

Secara khusus, pada setiap mangsa muncul gejala alam tertentu berupa tumbuh-gugurnya flora dan gerak-gerik fauna. Selain itu, pada suatu mangsa tertentu adalah waktu untuk dimulainya suatu pekerjaan bertani berdasarkan gejala alam yang hadir. Berikut ini merupakan deskripsi dari van Hien terkait kondisi di Jawa bagian barat serta Jawa bagian tengah dan timur pada setiap dimulainya suatu mangsa tertentu.

\begin{tabular}{|c|c|c|}
\hline \multirow[t]{2}{*}{ Musim } & \multicolumn{2}{|c|}{ Kondisi Alam dan Waktu Memulai Pekerjaan } \\
\hline & Jawa bagian barat & Jawa bagian tengah dan timur \\
\hline Kasa & $\begin{array}{l}\text { Daun-daun kering dan jatuh serta } \\
\text { tidak ada hujan }\end{array}$ & $\begin{array}{l}\text { Mulai membakar damen di sawah, } \\
\text { serta mulai menggarap tanah dengan } \\
\text { tanaman palawija }\end{array}$ \\
\hline Karo & Tanah merekah karena hawa panas & Tanaman palawija mulai tumbuh \\
\hline Katiga & $\begin{array}{l}\text { Mulai ada tanaman di sawah, } \\
\text { seperti tanaman kacang, semangka, } \\
\text { ubi, kacang tanah, mentimun dan } \\
\text { sebagainya }\end{array}$ & $\begin{array}{l}\text { Tanaman palawija mulai berbunga } \\
\text { dan berbuah }\end{array}$ \\
\hline Kapat & $\begin{array}{l}\text { Mata air surut serta sumur-sumur } \\
\text { menjadi kering }\end{array}$ & $\begin{array}{l}\text { Tidak ada tanaman di sawah, tanah } \\
\text { kering dan pecah, kurang air dan } \\
\text { panas }\end{array}$ \\
\hline Kalima & Mulai turun hujan sedikit & $\begin{array}{l}\text { Mulai turun hujan sedikit. Para } \\
\text { petani mulai membuat selokan dan } \\
\text { galengan }\end{array}$ \\
\hline Kanem & $\begin{array}{l}\text { Mulai muncul buah-buahan, } \\
\text { seperti mangga, jamblang, salak } \\
\text { dan sebagainya }\end{array}$ & $\begin{array}{l}\text { Mulai menggarap sawah dengan } \\
\text { menebar bibit }\end{array}$ \\
\hline
\end{tabular}




\begin{tabular}{|c|c|c|}
\hline Kapitu & Muncul banyak penyakit & Mulai menanam padi di sawah \\
\hline Kawalu & Musim kucing kawin & Padi mulai muncul \\
\hline Kasanga & $\begin{array}{l}\text { Mulai muncul bunyi gangsir atau } \\
\text { gareng }\end{array}$ & Padi mulai berisi \\
\hline Kasadasa & $\begin{array}{l}\text { Musimnya hewan berkaki empat } \\
\text { bunting }\end{array}$ & Padi mulai menguning \\
\hline Desta & Musimnya banyak anak burung & $\begin{array}{l}\text { Waktunya panen dan memotong } \\
\text { padi }\end{array}$ \\
\hline Sada & $\begin{array}{l}\text { Mulai muncul hawa yang sangat } \\
\text { dingin }\end{array}$ & Waktunya padi masuk ke lumbung \\
\hline
\end{tabular}

Sumber: Diolah dari Van Hien, H.A. 1897. De Petangan's of Tellingen der Javanen. Batavia: Albrecht \& Co. hlm., 57 - 58

Pada dasarnya, gejala alam serta pekerjaan di wilayah Jawa Barat serta Jawa Tengah dan Timur umumnya hampir sama. Di wilayah Jawa Barat (Tatar Sunda) perhitungan mangsa ini tercantum dalam Kitab Paririmbon. Dalam kitab ini dijelaskan pula pembagian mangsa, lamanya mangsa, serta gejala-gejala alam yang muncul pada setiap mangsanya, yakni: Mangsa Kasa ditandai dengan gugurnya dedaunan; Mangsa Karo ditandai dengan tanah belah-belah; Mangsa Katiga ditandai dengan liarnya hewan curut dan kuda; Mangsa Kapat ditandai dengan tidak adanya hujan serta mata air yang kering; Mangsa Kalima ditandai dengan turunnya hujan; Mangsa Kagenep ditandai dengan munculnya buah-buahan (musim buah); Mangsa Katujuh ditandai dengan banyaknya penyakit; Mangsa Kadalapan ditandai dengan kucing- kucing yang kawin; Mangsa Kasalapan ditandai dengan serangga tonggeret dan kasir yang bersuara; Mangsa Kasapuluh ditandai dengan hewan-hewan bunting; Mangsa Kasawelas ditandai dengan hewan-hewan terlihat memberi makan anakanaknya; serta Mangsa Kaduawelas ditandai dengan orang-orang jarang terlihat berkeringat (Sastra-Atmadja \& Gotama, 1950: 31-32).

Selain Paririmbon, persoalan waktu tanam tersebut tercantum pula dalam Serat Centhini. Dalam Serat Centhini, tertulis satu bab khusus perihal pranatamangsa. Setelah proses pembakuan waktu, dalam menentukan awal pekerjaan, para petani berpaku pada suatu penanggalan. Populernya penggunaan Kalender Masehi membuat penentuan musim dalam pranatamangsa pun berpaku pada setiap tanggal dan bulan pada kalender tersebut. Selain itu, seiring berkembangnya ilmu pengetahuan modern, gejala-gejala alam yang nampak pada setiap musim pun diterjemahkan dalam bahasa sains modern (meteorologi).

Menurut Sindhunata (2011: 4), setiap mangsa mempunyai watak dan pengaruh pada pengolahan tanaman. Penentuan mangsa yang terkesan mistis sesungguhnya didasarkan pada pengalaman nyata dan pengamatan rasional. Mengutip N. Daldjoeni dalam tulisan berjudul "Penanggalan Pertanian Jawa Pranata Mangsa (Proyek Javanologi, 1983) - dan bersumber pada buku sejarah para raja Surakarta yang disimpan di Museum Radya Pustaka, Sindhunata menjabarkan karakteristik pranatamangsa yang disandingkan dengan penjabaran gejala alam dalam sains modern.

1. Mangsa Kasa (22 Juni - 1 Agustus) berlangsung selama 14 hari. Mangsa ini memiliki watak Satya murca ing embanan atau permata yang terlepas dari cincin pengikatnya. Watak mangsa ini adalah masa tenang yang biasanya kering. Mangsa ini ditandai dengan daun-daun yang berguguran, serta belalang mulai 
membuat liang dan bertelur. Pada mangsa ini petani membakar batang padi yang tersisa di sawah dan mulai menanam palawija. Kondisi meteorologis mangsa kasa adalah sinar matahari 76\%, kelembapan udara 60,1\%, curah hujan 67,2 mm, dan suhu udara $24,4^{\circ} \mathrm{C}$

2. Mangsa Karo (2 - 24 Agustus) berlangsung selama 23 hari. Mangsa ini memiliki watak bantala renka yaitu tanah retak atau berbongkah. Pada mangsa ini hawa cenderung panas dan manusia mulai resah karena alam terasa kering dan panas. Bumi terlihat merekah karena memasuki masa paceklik. Palawija mulai tumbuh serta pohon randu dan mangga mulai bersemi. Kondisi meteorologis pada mangsa ini sama dengan mangsa kasa, tetapi curah hujan turun menjadi 32,2 mm.

3. Mangsa Katelu (25 Agustus - 17 September) berlangsung selama 24 hari. Mangsa ini memiliki watak suta manut ing bapa yang artinya anak menuruti bapak. Pada mangsa ini tanaman menjalar mulai tumbuh. Tanaman ini lah yang dianggap sebagai anak, sedangkan lanjarannya sebagai bapak. Mangsa ini ditandai dengan sumur-sumur mengering dan angin berdebu. Tanah tidak dapat ditanami karena panasnya cuaca dan air yang kurang. Palawija mulai dipanen pada musim ini, sedangkan bambu, gadung, temu, dan kunyit mulai tumbuh. Kondisi meteorologis mangsa ini adalah sama dengan mangsa karo, dengan curah hujan yang naik menjadi $42,2 \mathrm{~mm}$.

4. Mangsa Kapat (18 September - 12 Oktober) berlangsung selama 25 hari. Mangsa ini memiliki watak waspa kumembeng jroning kalbu yang artinya air mata yang tersimpan dalam hati. Watak tersebut dapat diartikan sebagai air yang mulai kering. Pada mangsa ini, petani masih harus menunda kegembiraan dan menunggu kekeringan benar-benar berlalu. Sawah-sawah belum dapat ditanami padi sehingga petani menyiapkan untuk penanaman padi gogo. Pohon randu berbuah dan burung-burung kecil, seperti pipit dan manyar mulai membuat arang dan bertelur. Kondisi meteorologis mangsa ini adalah sinar matahari $72 \%$, kelembapan udara $75,5 \%$, curah hujan $83,3 \mathrm{~mm}$, dan suhu udara mencapai $26,7^{\circ}$ C.

5. Mangsa Kalima (13 Oktober - 8 November) yang berlangsung selama 27 hari. Mangsa ini berwatak pancuran mas sumawur ing jagad yang artinya hujan yang tersebar di bumi - ditandai dengan turunnya hujan pertama. Manusia bergembira karena turunnya hujan, layaknya emas yang jatuh ke bumi. Para mangsa ini petani mulai mengolah sawah dan membuat irigasi, serta padi gogo mulai disebar. Pohon asam ditumbuhi daun muda, kunyit dan gadung berdaun, ular dan ulat pun mulai keluar. Kondisi meteorologis pada mangsa ini adalah sama dengan mangsa karo, namun curah hujan naik menjadi 151,1\%.

6. Mangsa Kanem (9 November - 21 Desember) yang berlangsung selama 43 hari. Mangsa ini berwatak rasa mulya kasucen yang artinya rasa mulya yang berasal dari kesucian. Sawah-sawah kembali hijau dan air mengalir dengan jernih. Musim ini ditandai dengan melimpahnya buah-buahan seperti durian, mangga, rambutan dan manggis. Manusia dipenuhi rasa syukur karena menerima limpahan berkah dari alam. Pada musim ini para petani mulai menbajak. Burung belibis mulai terlihat mencari mangsa di kolam-kolam dan kecoa serta lipas banyak ditemukan di parit. Kodisi meteorologis mangsa ini sama dengan mangsa sebelumnya, dengan curah hujan meninggi menjadi 402, $2 \mathrm{~mm}$. 
7. Mangsa Kapitu (22 Desember - 2 Februari) yang berlangsung selama 43 hari. Mangsa ini berwatak wisa kentar ing maruta yang artinya bisa terbang tertiup angin. Musim ini ditandai dengan datangnya penyakit dan banjir. Pada mangsa ini, alam terlihat kurang bersahabat. Para petani mulai menyebar bibit di tempat persemaian, di tengah curah hujan tinggi, angin kencang, dan sungai-sungai yang meluap. Kondisi meteorologis masa ini adalah kadar sinar matahari $67 \%$, kelembapan udara $80 \%$, curah hujan $501,4 \mathrm{~mm}$, serta suhu udara $26,2^{\circ} \mathrm{C}$.

8. Mangsa Kawolu (3 - 28 atau 29 Februari) yang berlangsung selama 26 atau 27 hari. Mangsa ini berwatak amjrah jroning kayun yang artinya tersebar merata di dalam hati. Musim ini ditandai dengan tanaman di sawah mulai menghijau, dan padi sudah meninggi. Uret (larva serangga) sudah banyak muncul, serta kucingkucing terlihat kawin, meski alam dipenuhi sambaran kilat. Curah hujan pada mangsa ini turun menjadi $371,8 \mathrm{~mm}$, yang artinya memberi kesegaran sekaligus menyapu kekeringan.

9. Mangsa Kasanga (1 - 25 Maret) yang berlangsung selama 25 hari. Mangsa ini berwatak wedaring wacana mulya yang artinya tersiarnya kabar gembira. Pada musim ini hewan-hewan seperti tonggeret (serangga, Cicadidae), jangrik, dan gangsir mulai berbunyi di mana-mana. Serangga seperti belalang juga mulai keluar. Padi sebagian sudah berbunga dan sudah berbuah. Pada masa ini, manusia mudah terkena penyakit. Namun, kekhawatiran terhadap penyakit tidak sebanding dengan kegembiraan di ujung musim hujan. Kondisi meteorologis masih sama dengan mangsa kawolu, namun curah hujan menujun menjadi $252,5 \mathrm{~mm}$.

10. Mangsa Kasapuluh (26 Maret - 18 April) yang berlangsung selama 24 hari. Alam memasuki masa terakhir dalam setahun, yakni mangsa mareng, yang terdiri atas mangsa kasapuluh, dhesta, dan saddha. Manga ini berwatak gedhong minep jroning kalbu yang artinya masa kehamilan hewan. Mangsa ini ditandai dengan hewan-hewan yang hamil dan burung-burung yang mulai bertelur. Padi mulai menguning dan saat yang tepat untuk memanen padi gogo. Mangsa ini terasa sedikit suram karena musim kemarau akan segera datang sehingga terasa sedikit lesu dan pusing. Kondisi meteorologis pada mangsa ini adalah sinar matahari $60 \%$, kelembapan udara $74 \%$, curah hujan $181,6 \mathrm{~mm}$, serta suhu udara $27,8^{\circ} \mathrm{C}$.

11. Mangsa Dhesta (19 April - $11 \mathrm{Mei}$ ) yang berlangsung selama 23 hari. Mangsa ini berwatak sotya sinarawedi yang artinya masa burung-burung menyuapi anaknya. Pada musim ini telur burung mulai menetas dan para petani mulai memanen padi. Curah hujan pada mangsa ini turun menjadi 129,1 mm.

12. Mangsa Saddha (12 Mei - 21 Juni) yang berlangsung selama 41 hari. Mangsa ini berwatak tirta sah saking sasana yang artinya air yang hilang dari tempatnya. Pada musim ini, curah hujan naik menjadi 149,2 mm, setelah itu hujan mulai habis dan kemarau mulai tiba. Air diibaratkan sebagai keringat dan sasana diibaratkan sebagai badan. Pada musim ini orang jarang berkeringat karena udara yang dingin. Para petani mulai menjemur padi dan memasukkannya ke dalam lumbung. Mereka mulai bersiap memasuki mangsa katiga, mangsa yang mengawali peredaran siklus setiap tahunnya. 


\section{PENUTUP}

Substansi pranatamangsa memang lahir dari kemampuan para petani dalam membaca tanda-tanda alam. Rasi bintang adalah suatu petunjuk. Pun dengan gerakgerik flora dan fauna. Alam masih menunjukkan adanya 'keteraturan' sehingga menjadi pertanda yang tetap terkait pergantian musim. Tanda-tanda alam sejatinya merupakan siklus tahunan. Namun, kadang sering terjadi ketidakseragaman dalam penetapan awal musim baru karena metode yang dipakai dalam penentuan musim, tidak lah sama. Untuk itu, pembakuan pun dilakukan mencakup panjang, serta permulaan dan akhir musim. Pranatamangsa telah dipraktikkan jauh sebelum datangnya orang-orang Eropa. Untuk itu, bagi orang-orang Eropa peminat kebudayaan Jawa, pranatamangsa merupakan sesuatu yang unik. Sistemnya sangat khas yang menggambarkan watak alam tropis Jawa.

Lalu, bagaimana dengan penerapan pranatamangsa pada masa sekarang? Masyarakat sekarang umumnya (mungkin) tidak mengenal sistem ini. Bahkan, bagi para petani sekalipun. Selain faktor modernisasi sistem pertanian, persoalan 'keteraturan' musim dan gejala-gejala perubahan iklim pun turut memberi andil bagi terlupakannya pranatamangsa. Masyarakat sangat sulit untuk menentukan awal musim kemarau atau musim penghujan pada masa kini. Gerak gerik flora dan fauna pun berubah. Produktivitas agraris pun berbanding lurus dengan terjadinya berbagai ketidakpastian iklim. Pada akhirnya, pranatamangsa hanya sebatas teori tanpa praktik yang sedang menanti kesirnaan - seperti yang diungkapkan Sindhunata.

\section{DAFTAR PUSTAKA}

Chodijm, Achmad. 2019. Serat Centhini Jilid I. Tangerang Selatan: Baca

Crawfurd, John. 1820. History of The Indian Archipelago Vol. I. Edinburgh: Archibald and Co.

Van Hien, H.A. 1897. De Petangan's of Tellingen der Javanen. Batavia: Albrecht \& Co

Ostmeier, J.J.B. 1914. Punten en Problem; Een en Ander Over Het Javaansche Volk. Semarang: H.A. Benjamins

Raffles, Thomas Stamford. 1830. The History of Java Vol. I. London: John Murray

Sastra-Atmadja, M \& Gotama. 1950. Paririmbon No.1. Bandung: M.I. Prawira-Winata Sindhunata dalam Bentara Budaya. 2011. Seri Lawasan Pranata Mangsa. Jakarta: KPG 